\title{
Assessment of pain experience in adults and children after bracket bonding and initial archwire insertion
}

\author{
Marcio José da Silva Campos¹, Marcelo Reis Fraga², Nádia Rezende Barbosa Raposo³, \\ Ana Paula Ferreira ${ }^{4}$, Robert Willer Farinazzo Vitral ${ }^{5}$
}

Introduction: Ninety five percent of orthodontic patients routinely report pain, due to alterations in the periodontal ligament and surrounding soft tissues, with intensity and prevalence varying according to age. Objective: This study aimed to assess toothache and buccal mucosal pain in adults and children during two initial phases of the orthodontic treatment. Methods: The intensity of toothache and buccal mucosal pain reported by 20 patients, 10 children (11-13 years) and 10 adults (18-37 years) was recorded with the aid of a Visual Analog Scale (VAS), during 14 days — 7 days with bonded brackets only and 7 days with the initial archwire inserted. Results: There was no significant difference in pain intensity among adults and children. After bracket bonding, $50 \%$ of the children and $70 \%$ of the adults reported pain. $70 \%$ of both groups reported pain after initial archwire insertion. While adults reported constant, low intensity, buccal mucosal pain, the children showed great variation of pain intensity, but with a trend towards decreasing pain during the assessment period. After initial archwire insertion the peaks of toothache intensity and prevalence occurred 24 hours in children and 48 hours in adults. Conclusions: In general, children reported pain less frequently than adults did, though with greater intensity.

Keywords: Pain. Orthodontic treatment. Visual Analog Scale.

Introdução: durante o tratamento ortodôntico, os pacientes rotineiramente relatam situações de dor, que ocorrem em até $95 \%$ dos casos. Essa dor é proveniente de alterações no ligamento periodontal e nos tecidos moles circundantes, e a sua intensidade e prevalência variam de acordo com a faixa etária dos pacientes. Objetivo: o objetivo desse estudo foi avaliar a experiência de dor nos dentes e na mucosa bucal em pacientes adultos e crianças durante duas fases iniciais do tratamento ortodôntico. Métodos: a intensidade de dor nos dentes e na mucosa bucal relatada por 20 pacientes, 10 crianças (11-13 anos) e 10 adultos (18-37 anos), foi registrada com uma Escala Visual Analógica (EVA) durante 14 dias, sendo 7 dias apenas com os braquetes colados e 7 dias com o arco inicial inserido. Resultados: não houve diferença significativa na intensidade de dor entre adultos e crianças. Após a colagem dos braquetes, $50 \%$ das crianças e $70 \%$ dos adultos relataram dor; e, após a inserção do arco inicial, a prevalência de relatos foi de $70 \%$ para ambos os grupos. Os adultos relataram dores constantes e de baixa intensidade na mucosa bucal, enquanto as crianças mostraram grande variação na intensidade, porém com tendência de diminuição durante o período de avaliação. Os picos de intensidade e prevalência de dor nos dentes ocorreram, respectivamente para crianças e adultos, 24h e 48h após a inserção do arco inicial. Conclusão: de modo geral, as crianças exibiram menor prevalência de relatos de dor, porém com maior intensidade do que os adultos.

Palavras-chave: Dor. Tratamento ortodôntico. Escala Visual Analógica.

${ }^{1}$ Professor, Department of Operative Dentistry, College of Dentistry, Juiz de Fora Federal University (UFJF).

${ }^{2}$ Professor, Department of Orthodontics, Juiz de Fora Federal University (UFJF).

${ }^{3}$ Associate Professor, Department of Radiology, Juiz de Fora Federal University (UFJF).

${ }^{4}$ Associate professor, Department of Parasitology, Microbiology and Immunology, Juiz de Fora Federal University (UFJF).

${ }^{5}$ Associate Professor, Department of Orthodontics and Pediatrics at Juiz de Fora Federal University (UFJF).
How to cite this article: Campos MJS, Fraga MR, Raposo NRB, Ferreira AP, Vitral RWF. Assessment of pain experience in adults and children after bracket bonding and initial archwire insertion. Dental Press J Orthod. 2013 Sept-Oct;18(5):32-7.

Submitted: December 14, 2010 - Revised and accepted: January 16, 2012

" The authors report no commercial, proprietary or financial interest in the products or companies described in this article.

Contact address: Marcio José da Silva Campos

Rua Paracatu, 568, Santa Terezinha, Juiz de Fora/MG - Brazil CEP: 36.046-040 -E-mail: drmarciocampos@hotmail.com 


\section{INTRODUCTION}

Patients undergoing orthodontic treatment routinely experience discomfort and pain referred not only to the dental supporting tissue (periodontal ligament $)^{1-6}$ due to force applied to the teeth,,$^{1,4,7-11}$ but also the surrounding soft tissues due to attrition caused by brackets and wires. $1,6,9,12,13$

Approximately $70 \%$ of orthodontic patients report pain, ${ }^{8}$ reaching $95 \%$ when only fixed appliances are used..$^{3,4,9,14}$ Due to subjectivity and influence from emotional, cognitive and cultural factors, ${ }^{15}$ pain reports may vary between groups with different characteristics. Among these characteristics, age has been the most frequently reported in the literature. Jones, ${ }^{7}$ Jones and Richmond ${ }^{16}$ reported that pain intensity and duration increased with patients' age. On the other hand, Brown and Moerenhout ${ }^{10}$ reported pain of higher intensity in adolescents, compared with children and adults, while Scheurer et $\mathrm{al},{ }^{4}$ Erdinç and Dinçer ${ }^{17}$ did not find any difference between children and adolescents as well as between adolescents and adults, respectively.

The aim of this study was to assess toothache and buccal mucosal pain experienced by adults and children after both bracket bonding and initial archwire insertion.

\section{MATERIAL AND METHODS \\ Subjects}

Twenty males (10 children and 10 adults) were selected for the study. The following inclusion criteria were used: Absence of deciduous teeth; willingness to undergo orthodontic treatment; no previous orthodontic treatment; good general health; disease-free oral mucosa and periodontal tissue.

The mean age of the children was $12.2 \pm 0.7$ years (ranging from 11 to 13 years), while the mean age of the adults was $24.7 \pm 4.2$ years (ranging from 18 to 37 years).

Because the experience of pain is influenced by emotional, cognitive and motivational factors as well as by family behavior standards, ${ }^{6,18}$ the following categories were excluded from the study: Dentists or dental students; close relatives or spouses of dentists or of subjects who had used a fixed appliance within the previous 12 months; those who feared dental treatment; and users of psychotropic drugs (antipsy- chotics, benzodiazepines, anti-seizure drugs or antidepressants), non-steroidal anti-inflammatory drugs (NSAIDs), and analgesics.

\section{Procedures}

This study was approved by the Ethics Committee of the UFJF. The participants, all volunteers, signed an informed consent after receiving full explanation about the procedures.

Toothache and buccal mucosal pain (lips and cheeks) were assessed for 14 days, divided into two phases: Bonding phase (days 1-7) and initial archwire phase (days 8-14). During the whole study period, patients did not use any analgesics or antiinflammatory drugs.

Pain intensity was recorded in a form containing two 100-mm Visual Analog Scales (VAS) ${ }^{19}$, one for toothache and the other for buccal mucosal pain (Figs 1 and 3). Forms were filled in by the patients on a daily basis, as soon as they woke up. The VAS ranged from "no pain" to "the worst possible pain".

On the morning of the day preceding the start of assessment, brackets and tubes (Mini Standard Edgewise, American Orthodontics, Wisconsin, USA) were bonded to the buccal surfaces of the upper incisors, canines, premolars and first molars of all patients. On the morning of the $7^{\text {th }}$ day, a 0.014 -in pre-formed arch (Titanium Memory Wire, 857-504, American Orthodontics, Wisconsin, USA) was totally inserted in the slots of all brackets and in the tubes, being then fixed with a 0.010 -in steel ligature wire.

\section{Statistical analysis}

Pain intensity and prevalence were analyzed by group and by phase. A descriptive statistical analysis was initially performed. Mann-Whitney's test was used to assess the significance of pain intensity between groups for each phase of the study. Wilcoxon's test was used to compare the differences between groups, determining the influence of patients' age. While Friedman's test was used to assess variation in pain intensity throughout the study period, Wilcoxon's test was used to assess the difference of pain intensity between consecutive days. The level of significance for the tests was 0.05. The software Statistical Package for the Social Sciences (SPSS 11.0.0) was used for the analyses. 


\section{RESULTS}

\section{Toothache intensity}

The daily means of toothache intensity reported by adults and children during the study period are shown in Figure 1. The peak of toothache intensity occurred on day 8 in children and on day 9 in adults.

The mean of toothache intensity for both groups is shown in Table 1. According to Wilcoxon's test, there was no within-group significant difference between the means of toothache intensity in the bonding and initial archwire phases. However, comparison between the daily pain intensity means showed a significant variation throughout the initial archwire phase in both groups (Table 1). According to Mann-Whitney's test, there was no significant difference between groups (Table 1).

Figure 2 shows the toothache prevalence for each day of both bonding and initial archwire phases. On the days when peaks of pain intensity were observed, 50\% of the children (day 8) and 70\% of the adults (day 9) reported toothache. During the bonding phase, 50\% of the subjects in both groups reported toothache on at least one of the seven days (Table 2), whereas 30\% of the adults and $10 \%$ of the children reported daily pain during this phase. On the initial archwire phase, however, $70 \%$ of the children and adults reported toothache (Table 2) and $60 \%$ of the adults and $10 \%$ of the children reported pain on a daily basis.

\section{Buccal mucosal pain}

Pain intensity on the oral mucosa, reported on a daily basis by the subjects throughout the study period, is shown in Figure 3. Pain was greater in children than in adults, on most days. In spite of the variability of pain intensity reported by the children, this group tended to have decreasing pain during the observation period (linear trend). Conversely, the adults reported lower and less variable buccal mucosal pain intensity.

There was no significant difference of buccal mucosal pain intensity between the bonding and initial archwire phases in both groups. However, a significant variation in daily buccal mucosal pain was observed throughout the bonding phase in the children (Table 1).

Table 1 - Toothache and buccal mucosal pain intensity during the bonding and initial archwire phases.

\begin{tabular}{|c|c|c|c|c|c|c|c|}
\hline & \multicolumn{3}{|c|}{ Bonding phase } & \multicolumn{3}{|c|}{ Initial archwire phase } & \multirow{2}{*}{$\begin{array}{c}\text { Difference } \\
\text { between phases }\end{array}$} \\
\hline & Mean (IR) & Range & $\begin{array}{l}\text { Variation } \\
\text { (P-value) }\end{array}$ & Mean (IR) & Range & $\begin{array}{l}\text { Variation } \\
\text { (P-value) }\end{array}$ & \\
\hline \multicolumn{8}{|l|}{ Toothache: } \\
\hline Children & $0.00(1.05)$ & $0-94.3$ & 0.130 & $0.00(25.50)$ & $0-94.3$ & $0.017^{\star}$ & 0.123 \\
\hline Adults & $0.00(3.85)$ & $0-94.4$ & 0.208 & $9.60(16.10)$ & $0-63.6$ & $0.008^{*}$ & 0.237 \\
\hline Difference between groups ${ }^{\star * *}$ & 0.342 & & & 1.000 & & & \\
\hline \multicolumn{8}{|l|}{ Buccal mucosal pain } \\
\hline Children & $0.00(0.00)$ & $0-94.3$ & $0.043^{*}$ & $0.00(0.00)$ & $0-80.5$ & 0.782 & 0.917 \\
\hline Adults & $0.00(4.20)$ & $0-35.3$ & 0.655 & $0.00(4.00)$ & $0-69.6$ & 0.112 & 0.893 \\
\hline Difference between groups ${ }^{\star * \star}$ & 0.934 & & & 0.408 & & & \\
\hline
\end{tabular}

IR - Interquartile range.

* significant variation in pain intensity throughout the study period (Friedman's test).

** Wilcoxon's test

*** Mann-Whitney's test.

Table 2 - Prevalence of pain reports during the bonding and initial archwire insertion phases

\begin{tabular}{|c|c|c|c|c|}
\hline & \multicolumn{2}{|c|}{ Children } & \multicolumn{2}{|c|}{ Adults } \\
\hline & Bonding phase & Initial archwire phase & Bonding phase & Initial archwire phase \\
\hline Toothache & $50 \%$ & $70 \%$ & $50 \%$ & $70 \%$ \\
\hline Buccal mucosal pain & $40 \%$ & $50 \%$ & $50 \%$ & $40 \%$ \\
\hline Toothache and buccal mucosal pain & $50 \%$ & $70 \%$ & $70 \%$ & $70 \%$ \\
\hline
\end{tabular}




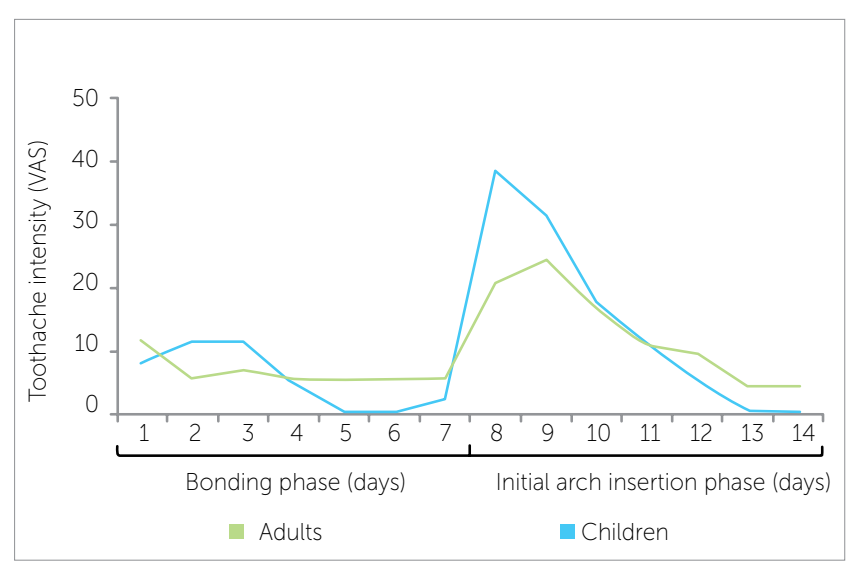

Figure 1 - Toothache intensity reported by the patients during the bonding (days 1-7) and initial archwire insertion (days 8-14) phases.

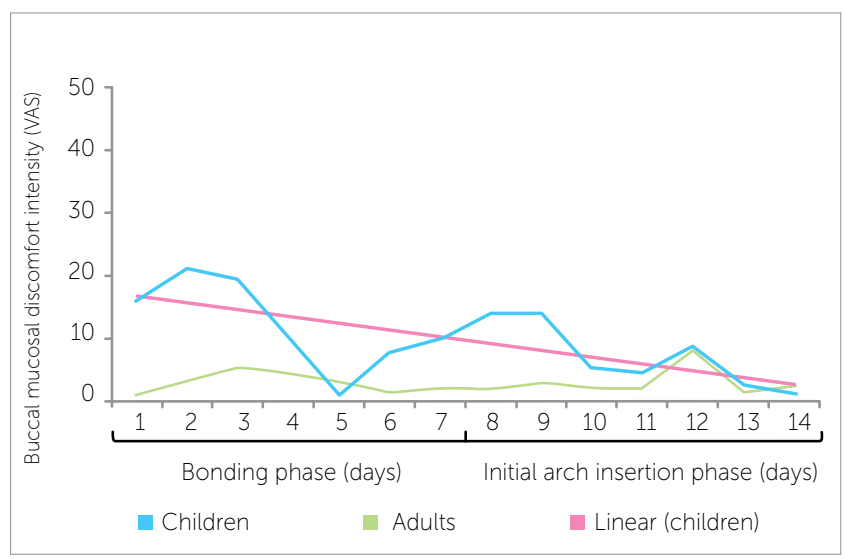

Figure 3 - Buccal mucosal pain intensity during the bonding (days 1-7) and initial archwire insertion (days 8-14) phases.

The intensity of buccal mucosal pain was greater in children than in adults on both study phases, although such difference was not significant (Table 1).

Figure 4 shows the prevalence of buccal mucosal pain on a daily basis during the bonding and initial archwire phases. The adults had higher prevalence of pain on most days, with little variation throughout the two phases. On the other hand, the children showed a progressive decrease from day 2 to day 7 , with an increase from day 8 on, the first day after initial archwire insertion. During the bonding phase, $40 \%$ of the children and $50 \%$ of the adults reported buccal mucosal pain, with $50 \%$ of the children and $40 \%$ of the adults reporting pain during the initial archwire phase (Table 2).

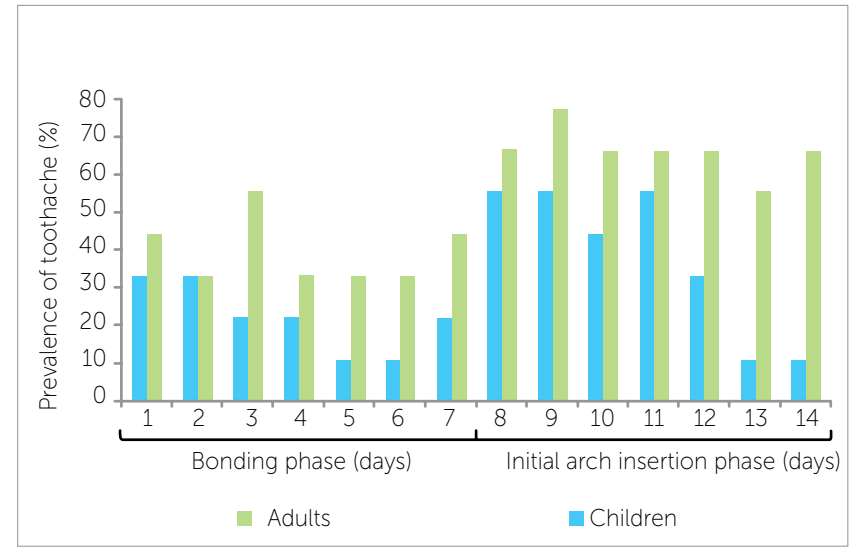

Figure 2 - Prevalence of patients reporting toothache during the bonding (days 1-7) and initial archwire insertion (days 8-14) phases.

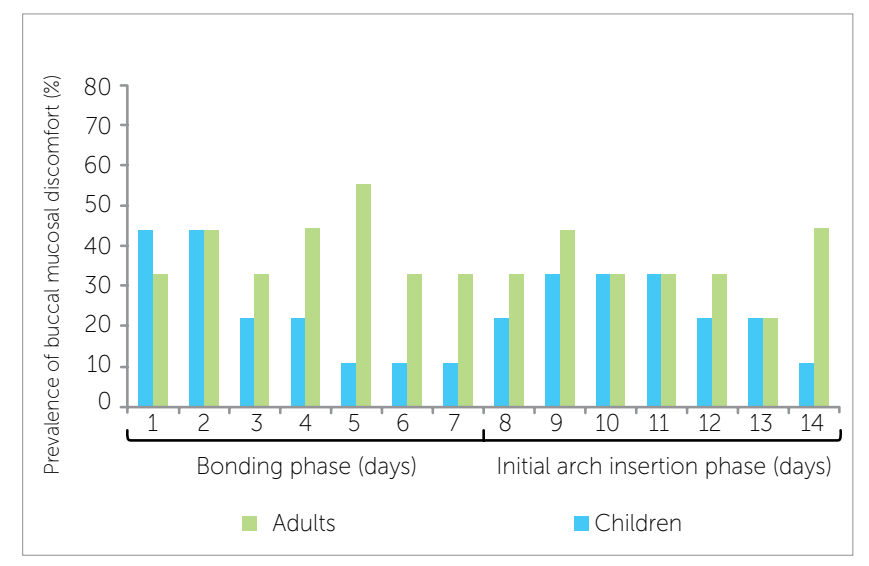

Figure 4 - Prevalence of patients reporting buccal mucosal pain during the bonding (days 1-7) and initial archwire insertion (days 8-14) phases.

\section{DISCUSSION}

Orthodontic treatment uses appliances to apply forces to the teeth, so that they can occupy more favorable esthetic and functional positions. Such devices injure the underlying oral mucosa, leading to discomfort and pain. ${ }^{1,3,6,9}$ In this study, the adults reported low-intensity and constant buccal mucosal pain during the observation period, while the children had great variability of pain intensity, but with a trend towards less intense pain throughout the study period. This trend towards pain intensity reduction was reported by Jones and Chan, ${ }^{3}$ who saw it as a consequence of inflammation and ulceration occurring at the beginning of treatment, occurring progressive adaptation of patients to the orthodontic appliances. 
Children reported higher intensity of buccal mucosal pain than the adults, although pain reported by the children was less prevalent on most days when compared with the adults. This shows that injury to the oral mucosa related to the brackets and wires causes pain in fewer children when compared with adults, although the affected children tend to develop greater suffering than the adults.

During the bonding phase, $50 \%$ of the subjects in both groups reported toothache, even without any force being applied to the teeth by the orthodontic appliance. This may have occurred due to the association of buccal mucosal pain with the discomfort caused by the lack of adaptation to the recently installed brackets, confusing the patients as to the exact kind of pain experienced during the first studied phase.

Forces applied to the teeth are transmitted to the supporting tissues (periodontal ligament and alveolar bone) which allow tooth mobility through inflammation, often associated with pain. ${ }^{1-11}$ Using the same type of initial archwire in all patients, regardless of their degree of tooth misalignment, resulted in the non-standardization of force application to the teeth, which has not been proved to influence the intensity of reported pain. ${ }^{3,16}$

The prevalence of reported pain after initial archwire insertion reaches $81 \%$ among adolescents, ${ }^{3}$ and ranges from 90 to $95 \%$ among adults. ${ }^{4,9}$ This higher pain prevalence among adults was not observed in this study, because although the adults had higher prevalence of toothache on all days of the initial archwire phase, the number of individuals reporting pain during this phase was the same in both groups.

After initial archwire insertion, pain reaches its peak in 24 hours, both as to intensity $3,4,7,11,17,20,21$ and prevalence. ${ }^{4,17,21}$ In this study, the peaks of toothache intensity and prevalence occurred 24 hours after initial archwire insertion in children (day 8 ) and 48 hours in adults (day 9). Toothache intensity and prevalence peaks oc- curred on day 9 among adults, because one individual reported pain just on this day. This changed the peak from 24 to 48 hours after initial archwire insertion.

Studies with orthodontic patients ${ }^{3,7,11}$ show that toothache intensity drastically and progressively decreases only after 72 hours after orthodontic force application, although in this study the beginning of the decrease in pain intensity was observed immediately after the peak, as reported by Sergl et al. ${ }^{22}$ The decrease was sustained until the penultimate day of assessment in both groups. This may be related to a reduction of perception concerning the proprioceptive stimulation, ${ }^{22,23}$ or to the fact that the patient has their attention no longer focused on pain. ${ }^{3}$ During the last two days (days 13 and 14), the groups presented a small difference between toothache intensity means, which was probably accounted for a higher prevalence of pain reports among the adults (70\%) compared to the children (10\%).

In general, during the study period, the children had lower prevalence of pain, and reported more intense pain compared to the adults, both for toothache and buccal mucosal pain. This higher pain intensity reported by the children may be due to the fact that the VAS uses the phrase "the worst possible pain". Because of their age, children are less likely to have had previous pain experiences than adults. ${ }^{24}$ Notwithstanding the fact, the VAS is recommended for individuals over 5 years of age. ${ }^{25,26}$

\section{CONCLUSION}

Pain was frequently reported by male children and adults from both groups after bracket bonding, but mainly after initial archwire insertion. A wide variability of pain intensity was observed throughout the study. Pain intensity, which was higher in children than in adults, progressively decreased immediately after reaching its peak, 48 or 72 hour after the orthodontic procedure, in both groups. 


\section{REFERENCES}

1. Kvam E, Bondevik $O$, Gjerdet NR. Traumatic ulcers and pain in adults during orthodontic treatment. Community Dent Oral Epidemiol. 1989;17:154-7.

2. Ngan P, Kess B, Wilson S. Perception of discomfort by patients undergoing orthodontic treatment. Am J Orthod Dentofacial Orthop. 1989;96(1):47-53.

3. Jones M, Chan C. The pain and discomfort experienced during orthodontic treatment: a randomized controlled clinical trial of two initial aligning arch wires. Am J Orthod Dentofacial Orthop. 1992;102(4):373-81.

4. Scheurer PA, Firestone AR, Burgin WL. Perception of pain as a result of orthodontic treatment with fixed appliances. Eur J Orthod. 1996;18(1):349-57.

5. Firestone AR, Scheurer PA, Bürgin WB. Patients' anticipation of pain and pain-related side effects, and their perception of pain as a result of orthodontic treatment with fixed appliance. Eur J Orthod. 1999:21(4):387-96

6. Bergius $M$, Kiliaridis S, Berggren U. Pain in orthodontics: a review and discussion of the literature. J Orofac Orthop. 2000;61(2):125-37.

7. Jones ML. An investigation into the initial discomfort caused by placement of an archwire. Eur J Orthod. 1984;6(1):48-54.

8. Oliver RG, Knapman YM. Attitudes to orthodontic treatment. Br J Orthod. 1985:12(4):179-88.

9. Kvam E, Gjerdet NR, Bondevik O. Traumatic ulcers and pain during orthodontic treatment. Community Dent Oral Epidemiol. 1987:15(2):104-7.

10. Brown DF, Moerenhout RG. The pain experience and psychological adjustment to orthodontic treatment of preadolescents, adolescents, and adults. Am J Orthod Dentofacial Orthop. 1991;100(4):349-56

11. Fernandes LM, Øgaard B, Skoglund L. Pain and discomfort experienced after placement of a conventional or a superelastic NiTi aligning archwire. A randomized clinical trial. J Orofac Orthop. 1998;59(6):331-9.

12. Pereira BR, Tanaka OM, Lima AAS, Guariza-Filho O, Maruo H, Camargo ES Metal and ceramic bracket effects on human buccal mucosa epithelial cells. Angle Orthod. 2009;79(2):373-9.

13. Kluemper GT, Hiser DG, Rayens MK, Jay MJ. Efficacy of a wax containing benzocaine in the relief of oral mucosal pain caused by orthodontic appliances. Am J Orthod Dentofacial Orthop. 2002;122(4):359-65
14. Lew KK. Attitudes and perceptions of adults towards orthodontic treatment in an Asian community. Community Dent Oral Epidemiol. 1993:21(1):31-5

15. International Association for the Study of Pain. Pain terms: a list with definitions and notes on usage. Pain. 1979;6:249-52

16. Jones ML, Richmond S. Initial tooth movement: force application and pain - a relationship? Am J Orthod .1985;88(2):111-6.

17. Erdinç AM, Dinçer B. Perception of pain during orthodontic treatment with fixed appliances. Eur J Orthod. 2004:26(1):79-85.

18. Krishnan V. Orthodontic pain: from causes to management: a review. Eur J Orthod. 2007:29(2):170-9.

19. Huskisson EC. Measurement of pain. Lancet. 1974;9:1127-31.

20. Polat Ö, Karaman Al. Pain control during fixed orthodontic appliance therapy. Angle Orthod. 2005:75(2):214-9.

21. Fleming PS, Dibiase AT, Sarri G, Lee RT. Pain experience during initial alignment with a self-ligating and a conventional fixed orthodontic appliance system: a randomized controlled clinical trial. Angle Orthod. 2009:79(1):46-50

22. Sergl HG, Klages $U$, Zentner A. Pain and discomfort during orthodontic treatment. Causative factors and effects on compliance. Am J Orthod Dentofacial Orthop. 1998:114(6):684-91.

23. Soltis JE, Nakfoor PR, Bowman DC. Changes in ability of patients to differentiate intensity of forces applied to maxillary central incisors during orthodontic treatment. J Dent Res. 1971;50(3):590-6.

24. Kiliaridis S, Bergius M. Pain and discomfort in orthodontics. In: Graber TM, Eliades T, Athanasiou AE. Risk management in Orthodontics: experts' guide to malpractice. Chicago: Quintessence; 2004. p. 131-43.

25. Langley GB, Sheppeard $H$. Problems associated with pain measurement in arthritis: comparison of the visual analogue and verbal rating scales. Clin Exp Rheumatol. 1984:2(3):231-4

26. Seymour RA, Simpson JM, Charlton JE, Phillips ME. An evaluation of length and end-phrase of visual analogue scales in dental pain. Pain. 1985:21(2):177-85 